\title{
What Factors Determines the FDI Net Flows in Africa? GMM and PMG Techniques
}

\author{
Abdelbagi E*, Azali M, Azman H and Norashidah Md Nor
}

Department of Economics, Universiti Putra Malaysia, Malaysia

\begin{abstract}
This study investigated the determinants of FDI in Africa during the time period from 1974 to 2013 , and annual data from the World Bank, African Union and United Nation. The study used GMM estimator and conducted three estimations, namely, 5 years, 8 years and 10 years average' estimations. Besides, to robustness check the results, the study used PMG estimator and therefore the full sample countries has been divided into three groups according to the income level, namely, low-income, lower middle-income and upper middle-income groups. The results suggested that the net inflows of the FDI in Africa are determined by economic growth, human capital, infrastructure, domestic investment and trade openness of the region.
\end{abstract}

Keywords: FDI; Robustness; Domestic investment; Infrastructure; Macroeconomics

\section{Introduction}

The net inflows of foreign direct investment in Africa have increased dramatically over the past years. In fact, in 2005 the total of the FDI inflows in Africa were US\$ 19.1 billion and increased significantly to US\$ 40.6 billion in 2013. The significant increase in the foreign direct investment inflows in Africa was because of the increases in the discoveries of the new African natural resources. In Sub-Saharan Africa, has increased by an average of $4.7 \%$ in 2013 , however it has dropped down in North Africa, in addition, the investment between African countries on the rise [1]. However, the FDI net inflows in the region is differs from sub-region to another, for instance, FDI net flows has significantly declined, in North Africa, by around $31 \%$, while FDI in Sub-Saharan Africa has increased by around $4.8 \%$. The gap between the North Africa and Sub-Saharan Africa has further expanded in term of FDI inflows, which led to more than $80 \%$ of Africa's FDI to be in SubSaharan Africa. Meanwhile the investment between African countries has steadily increased; the United Kingdom remains the lead investor in Africa. However, the foreign investors are mostly look for the most stable markets in the continent such as Nigeria, South Africa and Kenya for their safety and to maximize their profit, as well as investing in the new Emerging markets in the region and more consumer-related sectors [2].

Figure 1 shows that the net flows of the foreign direct investment in Africa increased dramatically over the past years. For instance, in 2015, the net flows of the FDI were $\$ 19.5$ billion and increased to $\$ 16.3$ billion in 2006. The net flows of FDI increased in 2007 to $\$ 29.9$ billion and then significantly increased to $\$ 40.6$ billion in 2013 . The net flows of the foreign direct investment in Africa have increased dramatically over

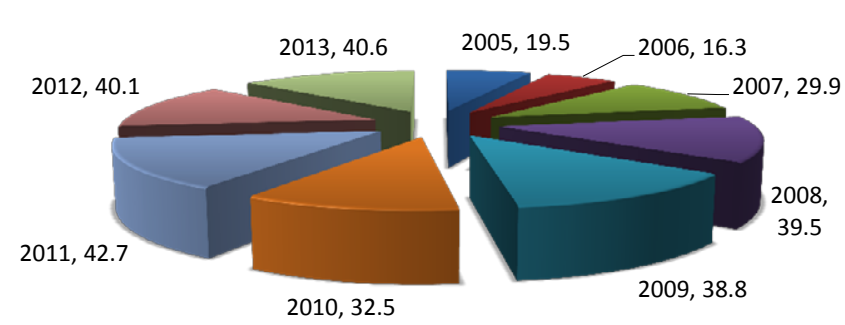

Figure 1: FDI Flows in Africa the past 7 years. As a result, to attract more foreign direct investment flows to come in the region, the attractiveness of the African countries for the foreign investors must be addressed. And the determinants of foreign direct investment in Africa need to be examined to introduce effective policies that attract more foreign direct investment flows to come in the region.

In other hand, In 2013, Africa has achieved the highest economic growth in the world, which was around $5.7 \%$. Also, the World Bank expected that Africa's GDP will continue rising by an average of over 6 percent a year in the period from 2013 to 2023. The Sub-Saharan Africa' countries posting more than $6.1 \%$ growth rate or even higher, while the other African countries grew between $4.1 \%$ to $6.2 \%$ each year Figure 2 [3]. Most importantly, African economy depends mostly on trade of goods and services. Figure 2 shows trade as a percentage of GDP in Africa, East Asia and Pacific, and Latin America and in the World. The figure shows that Africa has the highest percentage compared to other regions, in fact, in 2008 African trade reached its

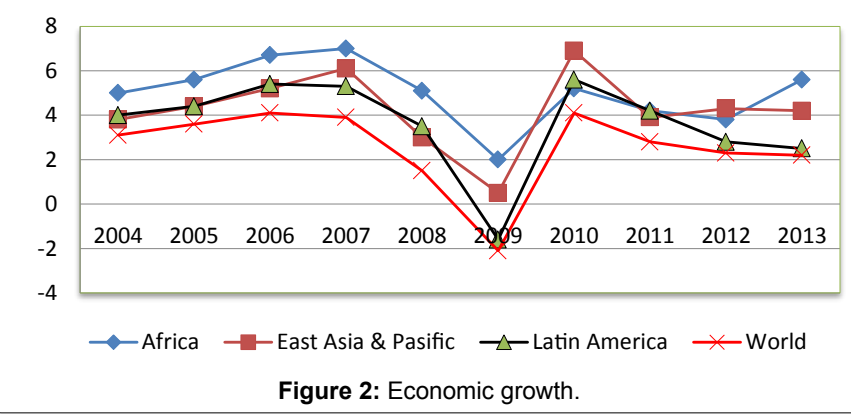

*Corresponding author: Abdelbagi E, Lecturer, Department of Economics, Universiti Putra Malaysia, Malaysia, Tel: +60109604001; E-mail: a.abdelbagi@hotmail.com

Received October 30, 2015; Accepted December 29, 2015; Published January 05, 2016

Citation: Abdelbagi E, Azali M, Azman H, Md Nor N (2016) What Factors Determines the FDI Net Flows in Africa? GMM and PMG Techniques. J Glob Econ 4: 170. doi:10.4172/2375-4389.1000170

Copyright: (c) 2016 Abdelbagi E, et al. This is an open-access article distributed under the terms of the Creative Commons Attribution License, which permits unrestricted use, distribution, and reproduction in any medium, provided the original author and source are credited. 
peak at $75.3 \%$ of African gross domestic product. As mentioned before, recent growth in Africa's GDP was because of the growth in sales of commodities and services plus the growth in the manufacturing in the region. To this end, trade as a percentage of GDP remains one of the most important factor which growing African economy. The impact of FDI on the economic growth is a well-investigated issue, however, the determinants of FDI in Africa remains a noticeable debated topic. Therefore, examining the determinants of the African inward FDI will help in introducing effective policies that attracts more FDI flows to come in the region.

\section{Literature Review}

The determinants of foreign direct investment in a country or an economy are differing from study to study. For instance, Mina found that institution quality, trade openness and infrastructure development encourage foreign direct investment inflows while human capital significantly discourages FDI inflows in GCC countries, he also found that oil prices have a negative impact on foreign direct investment flows in the region [4]. Wang et al. resulted that institution quality and industrial environment are statistically determinants of China's FDI outwards; they argue that political stability plays a significant role in determining the foreign direct investment outflows of the Chinese firms [5]. The political-economy and trade dynamics are found to be the most important factors that affecting the foreign direct investment inflows in Sub-Saharan Africa countries, while the production inputs play an important role in determining the FDI inflows followed by political stability in the host countries [2]. Moreover, economic growth attracts more FDI flows to come into the country; country with high economic growth is more attractive for the foreign investors than a country with lower economic growth.

In addition, electricity prices, export growth, import growth, discount rate and country risk index are the main determinants of foreign direct investment flows in Turkey [6]. The gross domestic products in Malaysia has a positive significant impact on foreign direct investment inflows, moreover, real exchange rate, financial development and macroeconomic uncertainty are positively related to FDI flows in the long-run in Malaysia. However, corporate income tax and social uncertainty have a negative impact on foreign direct investment, net flows in Malaysia [7]. In addition, human capital has found to be statistically one of the determinants of the foreign direct investment inflows, in fact, it is one of the most important determinants of the foreign direct investment and its importance is becoming greater through time [8]. Petri concluded that the foreign direct investment inflows in Asia, in contrast to other FDI flows, systematically favor hosts with relatively low technology achievement and relatively strong intellectual property rights regimes [9]. In other hand, trade openness, government stability and country risk index are the main determinants of the foreign direct investment inflows in Latin America [10]. Moreover, the market size of the host country plays an important role in attracting the Malaysian investors and companies in addition to the real effective exchange rate of the host country, international reserves and trade openness [11].

Bekhet and Al-smadi suggested that GDP, trade openness and money supply are playing important role in determining the foreign direct investment net inflows in Jordan, they found positive significant impact from those variables on the FDI flows in the long-run. Nonetheless, real interest rate and exchange rate of the home country are playing important role in determining the Chinese and Indian FDI outflows, the impact of the host country' real interest rate and exchange rate of is found to be positive and statistically significant on foreign direct investment of China and India in the long-run [12]. Gao et al. examined the importance of human capital mobility on determining the location of Chinese FDI outwards; they found that the two-way mobility of highly skilled Chinese students and scholars is significantly determined the Chinese outwards FDI in addition to the economic development in the host country [13]. Kindra et al. found that market size is one of the important determinants of foreign direct investment in Asian countries; they suggested that the consumption behavior in those countries significantly affects the long-run FDI, moreover, trade openness and economic growth are positively generate foreign direct investment inflows in the region [14].

Furthermore, political stability affects the long-run FDI flows in the host country while natural resources of the host country attract the Chinese outwards FDI addition to trade openness, gross domestic products and exchange rate of the host country [15]. In addition, Khan et al. states that political stability and government stability are both significantly affecting the foreign direct investment in the host country, while most of the country macroeconomic variables such as export, import, economic growth and trade openness are statistically significant in determining the net inflows of the foreign direct investment in a country [16]. The emergence of two major globalized delta economies, the critical effects and functions of a core city in promoting foreign direct investment into globalized delta economies and industry structure specialization in the periphery cities/countries with globalized delta economies are found to be statistically significant determinants of the foreign direct investment in China [17].

Moreover, trade openness plays a significant role in attracting foreign direct investment flows to come in the host country while the human capital doesn't play an important role in determining the foreign direct investment inflows in the home country [18]. Mina empirically examined the theoretical debate on the adoption of a best approach to reforming institutions identified by Rodrik in the context of property rights protection and FDI flows to eight MENA countries [19]. The first best approach comprises strengthening domestic institutional functions only, while the second best comprises in addition entering into force bilateral investment treaties and the interaction between functions and treaties. Empirically both approaches to reducing investment expropriation risk, encourage FDI flows. The positive effect of the second best approach depends on the success of the first best approach, suggesting the two approaches are complementary.

\section{Theoretical Foundation}

In this section we show the theoretical base of our study, we start by the neoclassical theory of investment where the firms facing the optimization problems. In each period, maximizing firm's profits will derive the optimal capital stock [20]. Given the below conventional Cobb-Douglas function ${ }^{1}$ of the production function:

$$
Y_{t}=f\left(K_{t}, L_{t}\right)=A K^{\alpha} L^{1-\alpha}
$$

Where $\mathrm{Y}$ is the total output, $\mathrm{K}$ is the stock of the capital, $\mathrm{L}$ is the labor, $t$ is the time period. The profit's function of a firm can be written as:

$$
\Pi_{t}=p_{t} Y_{t}-s_{t} I_{t}-w_{t} L_{t}
$$

Where, $\Pi_{t_{t}}$ denotes profit, $P_{t}$ is the output's price, $S_{t}$ is capital's

${ }^{1}$ In this assumption, the substation between labor and capital is totally complete which had known as so-called putty-putty technology. For the situations where the substation is allowed to vary between 0 to 1, please refer to (Baddeley, 2003) the so-called of putty-clay and clay-clay. 
price and $w t$ is the rate of the wage. Firms are going to maximizing the profit, thus, the current value of a firm can be stated as:

$$
\begin{aligned}
& V_{0}=\max E_{\varnothing_{0}} \int_{0}^{\infty} \Pi_{t} e^{-r t} d t=E_{\varnothing_{0}} \int_{0}^{\infty}\left[p_{t} Y_{t}-s_{t} I_{t}-w_{t} L_{t}\right] e^{-r t} d t \\
& \text { s.t. } \frac{d K}{d t}=I_{t}-\partial K_{t}=K_{t}^{*} \text { and } \mathrm{K}_{0} \text { is given. }
\end{aligned}
$$

The term $E^{2}$ is conditioned on the set of the information (Ø), which is available for the firms in each given period. To simplify, we will drop the time notation from now on.

$$
L=V_{0}+\int_{0}^{\infty} \gamma\left[(1-\partial K)-K^{*}\right] e^{-r t}
$$

This gives:

$$
L=\int_{0}^{\infty}\left[p Y-s I-w L+\gamma(1-\partial K)-\gamma K^{*}\right] e^{-r t} d t
$$

From here, we obtain the (Hamiltonian) $)^{3}$ current familiar value of the firm:

$$
H=p f(K, L)-s I-w L+\gamma(I-\partial K)
$$

Where, the costate variable in the above equation is the Lagrangian multiplier is the costate variable. Please note that, states the shadow price of the capital. To obtain the first order condition, differentiate the above Hamiltonian:

$$
\frac{\partial H}{\partial I}=-s+\gamma=0
$$

This means that, the shadow price of the capital equals to the opportunity cost of the capital.

$$
\frac{\partial H}{\partial L}=p f_{L}^{\prime}-w
$$

Now we can simply say that, firms should employ labors until the marginal revenue of the labor equals the wage of labors. Recalling the principle of maximization we obtain:

$$
\frac{\partial H}{\partial \gamma}=\frac{\partial K}{\partial t}=1-\partial K=0
$$

Simply, in equilibrium, the net investment should equal to zero and the depreciation of capital should equal to the gross investment. Thus, the marginal condition for the capital can be written as:

$$
\frac{\partial H}{\partial K}=p f_{K}^{,}-\gamma \partial=0
$$

the (Intriligator, 1971)' canononical equation requires that, the optimal output $\left(y^{*}\right)$ should equal $\left(\frac{-\partial H}{\partial K}\right)$. Therefore:

$$
-\frac{\partial H}{\partial K}=\frac{d}{d t}\left[e^{-r t} \gamma(t)\right]=\frac{\partial \gamma}{\partial t}-r \gamma
$$

this means that Equation (20) can be rewritten as:

$$
-p f_{K}^{,}+\gamma \partial=\frac{\partial \gamma}{\partial t}-r \gamma
$$
as:

Since $s=\gamma$, then $\frac{\partial s}{\partial t}=\frac{\partial \gamma}{\partial t}$. This implies that, $\frac{\partial H}{\partial K}$ can be rewritten

$$
p f_{K}^{,}+s \partial=\frac{\partial s}{\partial t}-r s
$$

${ }^{2}$ The term $E$ is the expectations operator.

${ }^{3}$ Please refer to (Intriligator, 1971) for more information regarding the Hamiltonian and the optimization.
Rearranging this, we get:

$$
p f_{K}^{\prime}=s\left[\partial+r-\left(\frac{\partial s}{\partial t}\right) / s\right] / p
$$

Note that $f_{K}=\frac{\partial Y}{\partial K} \partial Y / \partial K$, and user cost of capital, $C$, is defined as: $s[\partial+r-(\partial s / \partial t) / s]$, which means that:

$$
f_{K}^{\prime}=c
$$

Now we can derive the optimal capital stock $\left(K^{\star}\right)$ and the function of the investment. To do that, we will use the Cobb-Douglas technology, then the marginal product of the capital will be:

$$
\frac{\partial Y}{\partial K}=f_{K}^{,}=\alpha K^{1-\alpha} L^{1-\alpha}
$$

which can be stated as:

$$
\frac{\partial Y}{\partial K}=\frac{\alpha Y}{K}
$$

recalling Equation (15) and multiplying by $\left(b_{t}\right)$, we get:

$$
\frac{\partial H}{\partial K}=p \frac{\alpha Y}{K}=c
$$

to obtain the expression of the capital stock, solve for K:

$$
K^{*}=\frac{p \alpha Y}{c}
$$

Now, its easy to note that, the optimal capital stock $\left(K^{\star}\right)$ is depending on the output, the output's price and the cost of the capital (c). Therefore, the investment is now, the changes in the capital between a two periods:

$$
I=\frac{p \alpha Y}{c}-K_{t-1}^{*}
$$

From this end, investment depends on the total output in the economy, cost to use the capital stock, price of the output and the previous capital stock in the economy. However, this study will base on the above theory of investment and other empirical work of the economists mentioned in section 2 to examine the determinants of the inward FDI in Africa.

\section{Empirical Model, Methodologies and Data}

\section{Empirical model}

To investigate the determinants of the foreign direct investment inflows in African countries the study adopts a model that where FDI is the dependent variable and economic growth, human capital, infrastructure, trade and domestic investment are the independent variables. From this end, the study's empirical model is

$$
\ln F D I_{i t}=\alpha+\omega F D I_{i t-1}+\eta_{0} \ln G D P_{i t}+\eta_{1} \ln H_{i t}+\eta_{2} \ln T R_{i t}+\eta_{3} \ln K_{i t}+\eta_{4} \ln I F_{i t}+\mu_{i t}
$$

where FDI is foreign direct investment, GDP is real GDP, $\mathrm{H}$ is human capital indicator, TR is trade openness, $K$ is domestic investment or capital stock and $I F$ is infrastructure stock indicator, $\alpha, \eta, \eta_{1}, \eta_{2}, \eta_{3}, \eta_{4}$ are the slope parameters to be estimated, is an error term, $i$ refers to the country and $t$ refers to the time. Equation (21) tells that the foreign direct investment is determined by the variables of interest which include, the past value of FDI summarized by the lagged dependent variable $F D I_{i t-1}$ real GDP, human capital $H$ domestic investment $K$, trade openness TR and infrastructure stock $I F$.

\section{Methodology}

The study uses the generalized method of moments (GMM) to 
estimate the impact of economic growth, human capital, infrastructure, trade and domestic investment on the net inflows of foreign direct investment in African countries. In this regard, the study will average the full sample length into three averages, namely, 5 years average, 8 years average and 10 years average. In addition, the pooled mean group technique (PMG) will be used to robustness check the results of the GMM estimations, therefore, the full sample countries will be divided into three sub-groups according to the income level, namely, the lowincome group, the lower middle-income group and the upper middleincome group.

\section{GMM estimator}

In econometrics, the generalized method of moments (GMM) is a generic method for estimating parameters in statistical models. Usually we apply (GMM) for semi-parametric models, where the coefficients of interest is finite-dimensional. Besides, the full shape of the data's distribution function may not be known, and therefore the maximum likelihood estimation is not applicable. The method requires that a certain number of moment conditions were specified for the model. These moment conditions are functions of the model parameters and the data, such that their expectation is zero at the true values of the parameters. The GMM method then minimizes a certain norm of the sample averages of the moment conditions. The GMM estimators are known to be consistent, asymptotically normal, and efficient in the class of all estimators that do not use any extra information aside from that contained in the moment conditions. One of the GMM's features is the moment conditions increase with the time. Thus, the Sargan test performed to test the over-identification restrictions. There is convincing evidence that too many moment conditions introduce bias while increasing efficiency. Therefore, it suggested that a subset of these moment conditions should be used to take advantage of the trade-off between the reduction in bias and the loss in efficiency. Most importantly, GMM also eliminates any endogeneity that may be due to the correlation of these country specific effects and the right hand side repressors [21]. The moment conditions utilize the orthogonally conditions between the differenced errors and lagged values of the dependent variable.

\section{PMG estimator}

The pooled mean group (PMG) which introduced by Pesaran et al. is an intermediate estimator because it involves both pooling and averaging [22,23]. One advantage of the PMG is that it can allow the short-run dynamic specification to differ from country to country while the long-run coefficients are constrained to be the same. According to Pesaran and Smith, the traditional estimators such as fixed-effects, random-effects and generalized method of moments GMM can lead to inconsistent estimates in the long-run due to the slope heterogeneity bias [22]. Pesaran et al. introduced the PMG to overcome this problem associated with those estimators. PMG allows the short-run dynamic specification to vary across countries, while it considers the long-run coefficients to be the same [23].

\section{Data}

This study will use a panel dataset for African countries (50 countries) covering the period from 1974 to 2013. The data is been collected from World Development Indicators, World Bank, African Union and United Nations Development Program. Table 1 shows the variables that are used in this study and describe those variables, units of measurement and sources of the data.

\begin{tabular}{|c|c|c|c|}
\hline Variable & & Measurement & Source \\
\hline GDP & Real GDP & \$ Billion & WDI, World Bank \\
\hline ATE & Access to electricity & \% of population & WDI, World Bank \\
\hline ATW & Access to water & \% of population & WDI, World Bank \\
\hline FDI & Foreign direct investment & \$ Billion & WDI, World Bank \\
\hline SCH & School enrollment & $\%$ of population & WDI, World Bank \\
\hline TR & Trade Openness & $\%$ of GDP & World Bank \\
\hline K & Gross capital formation & $\%$ of & WDI, World Bank \\
\hline
\end{tabular}

Note: ATE, ATW are variables to proxy the infrastructure, SCH proxy the human capital in Equation (21).

Table 1: Data description.

\begin{tabular}{|c|c|c|c|c|c|c|}
\hline \multirow{2}{*}{} & \multicolumn{2}{|c|}{ Low income } & \multicolumn{2}{c|}{ Lower middle } & \multicolumn{2}{c|}{ Upper middle } \\
\cline { 2 - 7 } & IPS & LLC & IPS & LLC & IPS & LLC \\
\hline InGDP & $-2.53^{\star *}$ & -1.56 & -2.39 & $-2.97^{\star *}$ & -2.23 & $-2.67^{\star *}$ \\
\hline InFDI & $-3.29^{\star *}$ & $-5.53^{\star *}$ & $-3.58^{\star *}$ & $-6.11^{\star *}$ & $-4.34^{\star *}$ & $-3.32^{\star *}$ \\
\hline InSCH & $-2.59^{* *}$ & $-3.38^{\star *}$ & $-2.78^{\star *}$ & $-3.38^{\star *}$ & $-1.74^{\star *}$ & $0.70^{* *}$ \\
\hline InATE & $-2.32^{* *}$ & -1.28 & -2.37 & -3.22 & -1.28 & -2.84 \\
\hline InATW & -2.53 & -3.44 & -3.57 & -3.97 & -2.39 & -3.77 \\
\hline InTR & -5.27 & -3.27 & -3.78 & -2.37 & -2.89 & -2.23 \\
\hline InK & -2.63 & -3.49 & -3.89 & -2.17 & -2.36 & -4.34 \\
\hline
\end{tabular}

Note: ${ }^{* *}$ indicates significant at $5 \%$. At level, intercept and trend are included The lag length selected based on SIC. ATE, ATW are variables to proxy the infrastructure, $\mathrm{SCH}$ proxy the human capital in Equation (21).

Table 2: Panel unit root tests.

\section{Empirical Results}

\section{Unit root test}

All variables are tested for the unit root in level including intercept and time trend, and after taking first difference including only intercept. The lag length is determined according to Schwarz information criterion SIC. Table 2 shows the results of Im et al. IPS and Levin et al. LLC unit root tests for low income, lower middle income and upper middle income groups in African countries [24,25]. The findings for the low income group and lower middle income show that $\ln F D I, \ln S \mathrm{CH}$, $\ln T$ and $\ln L$ are stationary in level, showing that, the variables are $I(0)$. However, $\ln A T E$ have unit root in level, but it is stationary after taking the first difference. In addition, IPS and LLC show conflicting results for $\ln G D P$ in level, but both tests reveal that the variable stationary after the first difference. This enables us to conclude that all the variables for low income Sub-Saharan African countries are either $I(0)$ or $I(1)$. For the upper middle income group, both test reveal that $\operatorname{lnFDI}, \ln S C H$ and $\ln L$ are stationary variables or $I(0)$.Further, $\ln T, \ln P E E$ and all other variables are stationary after first difference. While, $\ln G D P$ is shown to have a contradictory result in level, however, it becomes stationary after taking first difference. Although, the IPS and LLC tests show contradictorv findings about $\ln G D P^{`}$ s order of integration. However, it can be co usidered as $I(1)$ to avoid the statistical consequences of treating $I(1)$ variable to be $I(0)$ Irz et al. [26]. Therefore, the general conclusion of the panel unit root test for low in ome and middle income countries is that the variables are $I(0)$ or $I(1)$

Table 3 reports the results of the Im et al. IPS and Levin et al. LLC unit root tests after taking the first difference [24,25]. The test conducted for low income, lower middle income and upper middle income groups for African countries. The lag length is determined according to Schwarz information criterion SIC. 


\begin{tabular}{|c|c|c|c|c|c|c|}
\hline & \multicolumn{2}{|c|}{ Low income } & \multicolumn{2}{|c|}{ Lower middle } & \multicolumn{2}{|c|}{ Upper middle } \\
\hline & IPS & LLC & IPS & LLC & IPS & LLC \\
\hline $\ln G D P$ & $-3.71^{* *}$ & $-9.89^{* *}$ & $-3.95^{\star *}$ & $-13.37^{* *}$ & $-3.78^{* *}$ & $-8.38^{* *}$ \\
\hline InFDI & $-4.89^{* *}$ & $-15.01^{* *}$ & $-5.67^{* *}$ & $-18.67^{* *}$ & $-4.43^{* *}$ & $-12.23^{* \star}$ \\
\hline $\mathrm{InSCH}$ & $-3.95^{\star *}$ & $-12.72^{* *}$ & $-3.48^{* *}$ & $-9.71^{* *}$ & $-4.43^{\star *}$ & $-9.39^{* *}$ \\
\hline InATE & $-3.44^{* *}$ & $-8.59^{* \star}$ & $-4.66^{* *}$ & $-11.43^{\star *}$ & $-4.22^{\star *}$ & $-7.55^{\star \star}$ \\
\hline InATW & $-4.37^{* *}$ & $-7.55^{\star *}$ & $-3.84^{* *}$ & $-12.49^{* *}$ & $-3.88^{* *}$ & $-9.42^{\star *}$ \\
\hline InTR & $-3.38^{* *}$ & $-9.97^{* *}$ & $-2.37^{* *}$ & $-7.87^{* *}$ & $-4.23^{* *}$ & $-8.92^{* *}$ \\
\hline InK & $-5.07^{\star *}$ & $-16.89^{* *}$ & $-4.88^{* *}$ & $-17.40^{* *}$ & $-5.32^{\star *}$ & $-11.48^{* \star}$ \\
\hline
\end{tabular}

Note: ${ }^{* *}$ indicates significant at $5 \%$. At level, intercept is included. The lag length selected based on SIC.

Table 3: Unit root test (first difference).

\begin{tabular}{|l|l|l|l|l|l|l|}
\hline \multirow{2}{*}{} & \multicolumn{2}{|c|}{ Low income } & \multicolumn{2}{c|}{ Lower middle } & \multicolumn{2}{c|}{ Upper middle } \\
\cline { 2 - 7 } & PP-Stat & ADF-St & PP-Stat & ADF-St & PP-Stat & ADF-St \\
\hline Within-dimension & $-4.09^{* *}$ & $-4.98^{* *}$ & $-1.87^{* *}$ & $-2.13^{* *}$ & $-2.28^{* *}$ & $-3.38^{* *}$ \\
\hline Between-dimension & $-8.13^{* *}$ & $-7.91^{* *}$ & $-3.89^{* *}$ & $-3.33^{* *}$ & $-5.43^{* *}$ & $-6.83^{* *}$ \\
\hline
\end{tabular}

Note: ${ }^{* *}$ shows significant at $5 \%$. The results included intercept and no trend. Lag length selection based on SIC

Table 4: Cointegration test.

\begin{tabular}{|c|c|c|c|}
\hline & 5 Years & 8 Years & 10 Years \\
\hline $\ln F D I_{t-1}$ & $0.171^{\star \star \star}(0.027)$ & $0.271^{* *}(0.099)$ & $0.006^{* \star}(0.002)$ \\
\hline $\ln G D P$ & $0.328^{\star \star \star}(0.073)$ & $0.711^{* \star \star}(0.212)$ & $0.042^{* \star}(0.012)$ \\
\hline $\mathrm{InSCH}$ & $0.771^{* * *}(0.129)$ & $0.734^{* *}(0.301)$ & $0.601^{* *}(0.201)$ \\
\hline InATE & $0.894^{\star \star \star}(0.088)$ & $0.970^{* *}(0.359)$ & $0.022^{\star \star}(0.004)$ \\
\hline InATSW & $0.826^{* \star \star}(0.273)$ & $0.062^{\star \star \star}(0.009)$ & $0.153^{* \star}(0.044)$ \\
\hline InTR & $0.643^{* * *}(0.204)$ & $0.011^{* *}(0.004)$ & $0.302^{\star \star \star}(0.117)$ \\
\hline $\ln K$ & $0.865^{\star \star *}(0.140)$ & $0.629^{*}(0.328)$ & $0.539^{\star \star}(0.390)$ \\
\hline Constant & $-16.516^{\star \star *}(1.483)$ & $-11.240^{\star \star \star}(3.522)$ & $-27.549(8.223)$ \\
\hline Sargan test: p-value & 0.4785 & 0.4575 & 0.4115 \\
\hline AR1: p-value & 0.0033 & 0.0016 & 0.0000 \\
\hline AR2: p-value & 0.8782 & 0.1032 & 0.8374 \\
\hline
\end{tabular}

Note: $p$-value indicates the level of the significance. Between ( ) are the standard errors. ${ }^{* * *}{ }^{* *}$ and ${ }^{*}$ indicates significant at $1 \%, 5 \%$ and $10 \%$, respectively. ATE, ATW are variables to proxy the infrastructure, $\mathrm{SCH}$ proxy the human capital in Equation (21)

Table 5: GMM results.

\section{Co-inegration test}

Table 4 presents that the Pedroni cointegration test findings for PP-statistics and ADF-statistics for between and within groups, respectively [27]. The findings of co-integration test provide evidence of long run relationship between variables for low-income, lower middle-income and upper middle-income countries. This enables us to estimate the long run and short run coefficients using pooled mean group estimation technique.

\section{GMM results}

Table 5 shows the results of the 5 years, 8 years and 10 years of GMM estimations. The results reveal that FDI is totally depend on the past value of the foreign direct investment which summarized by the lagged dependent variable $\left(F D I_{t-1}\right)$. The coefficient value $(0.322)$ of the lagged dependent variable reflects the importance of the past values of the foreign direct investment inflows in determining the current value of the foreign direct investment inflows in Africa. Also, the results suggest that economic growth in Africa is one of the determinants of the foreign direct investment, and its impact on FDI has found to be positive and statistically significant since the p-value is (0.000). Most importantly, school enrollment, as a proxy of human capital, has appeared to have positive significant impact on FDI flows. Therefore, education human capital has important role in determining the foreign direct investment flows in Africa. Moreover, the infrastructure' indicators have significant impact on FDI in Africa; access to electricity has found to be highly determine the inflows of the foreign direct investment in the region since its impact on FDI is positive and statistically significant. In addition, access to safe water has important role in determine the FDI inflows due to its positive and significant impact on the foreign direct investment inflows in African countries. In the same line, trade openness has positive significant impact on FDI, which implies the more trade openness the more FDI flows in the region. Similarly, domestic investment (capital) significantly attracts more foreign direct investment flows to come in the continent.

\section{PMG results}

Table 6 reports the results of the PMG estimations for low-income, lower middle-income and upper middle-income groups. The results of the low-income group are reported in the second column, and for the lower middle-income group in the third column, and for the upper middle-income in the fourth column.

The results indicate that economic growth is positively contributes to FDI and its impact is statistically significant on the FDI inflows. In addition, the impact of the human capital' indicator has found to be statistically significant on the foreign direct investment inflows in Africa. In addition, access to electricity and access to safe water have positive and statistically significant impacts on foreign direct investment flows in all income groups. This is not only implies that infrastructure is very important to attract FDI, but also facilitate trade and doing business in this income the continent. Moreover, trade openness and domestic investment have positive significant impact on FDI in this group. The values of the error correction terms (ECT) is negative and statistically significant; it shows that any deviation from the long run expected value is adjusted by $53.7 \%, 50.6 \%$ and $48 \%$ annually. In the short-run, all variable have insignificant impact on foreign direct investment flows except human capital in the upper middle-income group.

\section{Results and Discussion}

The results obtained from the GMM estimations suggested that economic growth is one of the main determinants of the foreign direct investment flows in African countries. The three GMM estimations resulted that, the impact of economic growth on FDI is positive and statistically significant. This finding is in line with Chowdhury and Mavrotas, Tolentino, Bilgili who also found that economic growth is positively contributes to the foreign direct investment $[6,15,28]$. This finding reveals that high economic growth in a country will attract more FDI flows to come in the country. Gao et al. examined the factors that determining the Chinese FDI outflows; they argue that economic development in the host country derived the Chinese FDI outflows. The results of this study confirm this point; they show that, the more economic growth the more foreign direct investment flows in the region [14]. African' economic growth has increased in the last decades and it shown to be the highest economic growth rate in the world (Figure 2), while the FDI inflows in Africa has increased dramatically over the last years (Figure 1) which confirms the study's finding that economic growth attract more FDI flows.

The robustness check results, which obtained from the pooled mean group estimations, confirmed that the GMM results are robust. For all 


\begin{tabular}{|c|c|c|c|c|c|c|}
\hline & \multicolumn{2}{|c|}{ Low-income } & \multicolumn{2}{|c|}{ Lower middle-income } & \multicolumn{2}{|c|}{ Upper middle-income } \\
\hline & L-run Model & S-run Model & L-run Model & S-run Model & L-run Model & S-run Model \\
\hline InGDP/ $/ n G D P$ & $0.501^{* * *}(0.186)$ & $1.240(6.880)$ & $0.333^{* *}(0.139)$ & $0.0001(0.0001)$ & $0.736^{* * *}(0.103)$ & $-0.02(.002)$ \\
\hline $\mathrm{InSCH} / \Delta \mathrm{InSCH}$ & $0.235^{\star *}(0.0395)$ & $-0.086(1.64)$ & $0.036^{\star * *}(0.009)$ & $0.015(0.026)$ & $0.021^{* * *}(0.008)$ & $0.233^{* *}(0.097)$ \\
\hline InATE I $\triangle$ InATE & $0.061^{* * *}(0.019)$ & $-0.086(1.64)$ & $0.083^{* * *}(0.008)$ & $-0.145(0.092)$ & $0.854^{* *}(0.363)$ & $-0.245(0.874)$ \\
\hline $\operatorname{InATW} / \triangle \operatorname{InATW}$ & $0.029^{\star * *}(0.011)$ & $-0.057(0.19)$ & $0.089^{* * *}(0.010)$ & $-0.111(0.202)$ & $0.066^{* * *}(0.013)$ & $0.062(0.061)$ \\
\hline $\ln T R / \Delta / n T R$ & $0.028^{\star \star \star}(0.006)$ & $0.005(0.013)$ & $0.017^{\star * *}(0.005)$ & $-0.015(0.010)$ & $0.007^{\star * \star}(0.002)$ & $0.004(0.007)$ \\
\hline $\operatorname{lnK} / \Delta / n K$ & $0.369^{*}(0.215)$ & $0.107(0.198)$ & $0.515^{\star * *}(0.180)$ & $0.375(0.198)$ & $0.929^{* * *}(0.249)$ & $0.438(0.412)$ \\
\hline$E C T_{t-1}$ & \multicolumn{2}{|c|}{$-0.537^{\star * *}(0.064)$} & \multicolumn{2}{|c|}{$-0.506^{* * *}(0.06)$} & \multicolumn{2}{|c|}{$-0.480^{* \star \star}(0.072)$} \\
\hline C & \multicolumn{2}{|c|}{$0.995^{\star \star \star}(0.198)$} & \multicolumn{2}{|c|}{$1.410^{* * *}(0.28)$} & \multicolumn{2}{|c|}{$-2.923^{* * *}(0.503)$} \\
\hline Log Likelihood & \multicolumn{2}{|c|}{-980.96} & \multicolumn{2}{|c|}{$-479.6 .6$} & \multicolumn{2}{|c|}{-522.4} \\
\hline Hausman test $p-v$ & \multicolumn{2}{|c|}{0.5915} & \multicolumn{2}{|c|}{0.2252} & \multicolumn{2}{|c|}{0.0517} \\
\hline
\end{tabular}

Note: ${ }^{* * *},{ }^{* *}$ and ${ }^{*}$ indicates significant at $1 \%, 5 \%$ and $10 \%$, respectively. Between ( ) are the standard errors. The ARDL model $(1,1,1,1,1,1)$ used uniform lags. Note: ATE ATW are variables to proxy the infrastructure, $\mathrm{SCH}$ proxy the human capital in Equation (21).

Table 6: PMG results.

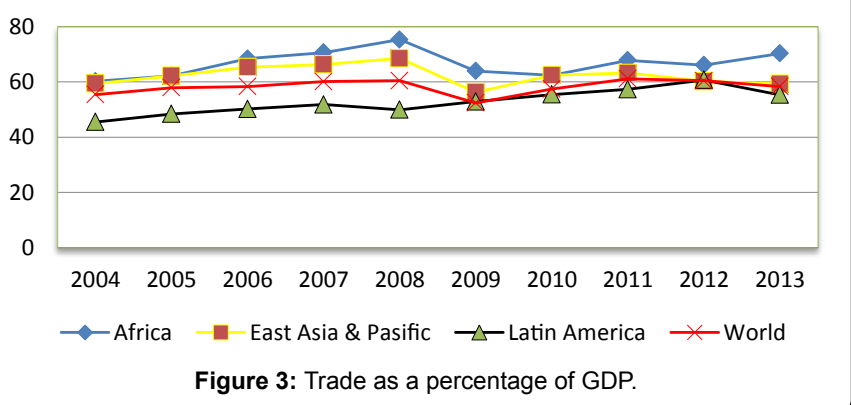

income groups, PMG results show that economic growth has positive and statistically significant impact on foreign direct investment. Therefore, economic growth is one of the FDI determinants in these groups. In this regards, the policy-makers in the low-income group, lower middle-income group and upper middle-income group should introduce polices that enhance the development activities in the region. This will not only increase their attractiveness for the FDI flows to come in the country, but also will help those countries to benefit more from the FDI positive spill-over effects.

The GMM estimations suggest human capital indicator, which used in the estimations, has positive significant impact on the foreign direct investment flows in Africa. The indicator used to proxy the human capital is school enrolment. The GMM 5 years average, 8 years average and 10 years average results reveal that human capital is one of the determinants of the FDI flows in the region. The above finding is in line with Wang et al. who examined the determinants of the outward FDI of the Chinese firms, they concluded that institutional, industrial environment and human capital development have important role in deriving the outward FDI of the Chinese firms [5]. Kolstad and Wiig found that outward FDI of China attracted only by the large markets and large natural resources, their finding is in line with results of the GMM estimation in this study regarding the human capital [29]. The robustness check results, the PMG results, show that the results of the GMM estimations are robust.

The pooled mean group estimations, which conducted for all income groups show that human capital' indicator, school enrollment, have positive significant impact on foreign direct investment net flows in the continent, which confirms the GMM results. The previous findings are in line with Noorbakhsh et al. who concluded that human capital is statistically significant determinant of foreign direct investment [8].
Also, it is one of the most important determinants of the foreign direct investment, they argue that the human capital is very important in attracting the foreign direct investment flows, and its importance has become increasingly greater through time. From this end, all income groups in Africa have to extremely develop and improve their human capital stock and have to invest and spend more in this regard. So that the attractiveness of the human capital for the foreign investors become higher and the FDI flows start to come in the region.

The three GMM estimations and all PMG estimations show that the impact of infrastructure on foreign direct investment is positive and statistically significant when using access to electricity and access to safe water as proxies of infrastructure. The results are in line with Mina who suggested that infrastructure development is significantly encouraging the foreign direct investment flows to come in the host country [4] Thus, it is very important to develop the electricity and water sources in Africa in order to attract more foreign direct investment flows to come in the region. Most importantly, access to electricity and access to safe water in Africa are the lowest in the world, even though, those two infrastructure indicators have important role in attracting the foreign direct investment flows to come in the region since their impact on the FDI is positive and statistically significant. In this regards, African policy-makers are advised to develop the existing electricity and water sources and to create more sources in order to facilitate the doing business in Africa since the needs of these two sources especially in the industrial sector in the region.

However, the availability of the electricity and water sources is the major concern when the investors aiming to make a decision regarding their investment destination. The electricity' infrastructure is facilitating the manufacturing procedures, because its supply is highly associated with the stability of the industrial sector and the economy. In other hand, water supply is very important for the industry and agricultural sectors and all society in the economy. According to researchers at the Overseas Development Institute; the lack of infrastructure in many developing countries represents one of the most significant limitations to economic growth and achievement of the Millennium Development Goals (MDGs) [30]. Pushing this further, infrastructure investments and maintenance can be very expensive, especially in such as areas as landlocked, rural and sparsely populated countries in Africa, it has been argued that infrastructure investments contributed to more than half of Africa's improved growth performance between 1990 and 2005, and increased investment is necessary to maintain growth and tackle poverty. The returns to investment in infrastructure are very significant, with on average thirty 
to forty percent returns for telecommunications (ICT) investments, over forty percent for electricity generation, and eighty percent for roads [31]

Besides, investment in infrastructure is part of the capital accumulation required for economic development and may have an impact on socioeconomic measures of welfare. The causality of infrastructure and economic growth has always been in debate. In developing nations, expansions in electric grids, roadways, and railways show marked growth in economic development. However, the relationship does not remain in advanced nations who witness more and more low rates of return on such infrastructure investments. Nevertheless, infrastructure yields indirect benefits through the supply chain, land values, small business growth, consumer sales, and social benefits of community development and access to opportunity. From this end, a hard work must be done, and more investment in infrastructure stock especially in electricity and water source is needed to improve the existing infrastructure and create more to attract foreign direct investment net inflows to come into the region. Thus, the results advise African policy-makers to invest more and spend more to achieve the targeted economic growth for the good of the region. This because the study results are suggesting that access to electricity and access to safe water are both statistically determinants of the foreign direct investment net inflows in all African countries and all income level group of the region countries [32].

Trade as a percentage of GDP is determine the FDI flows in Africa, all GMM and PMG estimations showed the same significant impact of trade on FDI. Moreover, African economy depends on trade of good and services (Figure 3), also, Africa experienced high economic growth in the past years, and FDI flows increased in the region. Thus, and since the significant impact of FDI on growth, policy-makers should introduce effective polices that facilitate trade and doing business. This will not only contribute to economic growth directly, but also will attract more FDI flows to come in the region and enhance the development activities in the continent. However, African countries should protect their domestic industries to reduce the huge import among the African countries, this will however, grow the economy and develop other sectors in the region. Pushing this further, reducing the barriers that face domestic exporters and decrease the cost and tax associated with export will lead to further growth among the African nations. Also, organizing trade procedures in Africa may help in creating more job opportunities, and somehow, help in reducing poverty among the nations through increasing the income of individuals.

\section{Conclusion}

This study examined the determinants of the net inflows of the foreign direct investment in Africa. The study based on the neoclassical theory of investment and other empirical work of the economists around the World to obtain the suggested determinants of the FDI in a country. Moreover, the study covered 50 African countries in the time period from 1974 to 2013, using annual data from the World Bank, African Union and United Nation. In terms of econometrics, the study used two econometrics methods in order to get robust results that are GMM and PMG. Pushing this further, the study conducted three GMM' estimations, namely, 5 years average estimation, 8 years average' estimation and 10 years average estimation. Besides, the study used the Pooled Mean Group (PMG) to robustness check the results of the GMM' estimations, in this regards, the study divided the full dataset into three groups according to the income level, namely, low-income, lower middle-income and upper middle-income groups.
Most importantly, the empirical results suggest that FDI inwards, in Africa and all income levels, are determined by economic growth, trade openness, domestic investment, human capital and infrastructure during the period of interest.

\section{References}

1. Gohou G, Issouf S (2012) Does Foreign Direct Investment Reduce Poverty in Africa and Are There Regional Differences? World Development 40: 75-95.

2. Bartels FL, Francesco N, Nicola ET (2014) FDI in Sub-Saharan Africa: A Longitudinal Perspective on Location-Specific Factors (2003-2010). International Business Review 23: 516-29.

3. World Bank (2013) Doing Business 2013.

4. Mina W (2007) The Location Determinants of FDI in the GCC Countries Journal of Multinational Financial Management 17: 336-48.

5. Wang C, Junjie H, Mario K, Agyenim B (2012) What Drives Outward FD of Chinese Firms? Testing the Explanatory Power of Three Theoretical Frameworks. International Business Review 21: 425-38.

6. Bilgili F, Nadide SHT, Ibrahim D (2012) The Determinants of FDI in Turkey: A Markov Regime-Switching Approach. Economic Modelling 29: 1161-69.

7. Choong CK, Siew-Yong L (2010) The Determinants of Foreign Direct Investment in Malaysia: A Revisit. Global Economic Review 39: 175-95.

8. Noorbakhsh F, Alberto P, Ali Y (2001) Human Capital and FDI Inflows to Developing Countries: New Empirical Evidence. World Development 29: 15931610.

9. Petri PA (2012) The Determinants of Bilateral FDI: Is Asia Different? Journal of Asian Economics 23: 201-9.

10. Sánchez M, Miguel E, Rafael De A, Gonzalo E (2014) Do Changes in the Rules of the Game Affect FDI Flows in Latin America? A Look at the Macroeconomic, Institutional and Regional Integration Determinants of FDI. European Journal of Political Economy 34: 279-99.

11. Goh SK, Koi NW (2011) Malaysia's Outward FDI: The Effects of Market Size and Government Policy. Journal of Policy Modeling 33: 497-510.

12. Bekhet HA, Raed WAS (2015) Determinants of Jordanian Foreign Direct Investment in FI Ows : Bounds Testing Approach. Economic Modelling 46: 27-35.

13. Gao L, Xiaohui L, Huan Z (2013) The Role of Human Mobility in Promoting Chinese Outward FDI: A Neglected Factor? International Business Review 22 . 437-49.

14. Kindra GS, Nicolino S, Norma M (1998) The Role of Marketing in FDI Generation: Evidence from ASEAN Countries. International Business Review 7: 399-421.

15. Tolentino PE (2010) Home Country Macroeconomic Factors and Outward FDI of China and India. Journal of International Management 16: 102-20.

16. Khan MA, Muhammad ZK, Khalid Z, Danish I (2014) Questing the Three Key Growth Determinants: Energy Consumption, Foreign Direct Investment and Financial Development in South Asia. Renewable Energy 68: 203-15.

17. Tuan C, Ng LFY (2007) The Place of FDI in China's Regional Economic Development: Emergence of the Globalized Delta Economies. Journal of Asian Economics 18: 348-64.

18. Aizenman J, Ilan N (2006) FDI and trade-Two-Way Linkages? The Quarterly Review of Economics and Finance 46: 317-37.

19. Mina WM (2012) The Institutional Reforms Debate and FDI Flows to the MENA Region: The 'Best' Ensemble. World Development 40: 1798-1809.

20. Jorgenson D (1967) The Theory of Investment Behavior. National Bureau of Economic Research 7: 129-88.

21. Baltagi BH, Demetriades PO, Law SH (2009) Financial Development and Openness: Evidence from Panel Data. Journal of Development Economics 89 285-96.

22. Pesaran MH, Ron S (1995) Estimating Long-Run Relationships from Dynamic Heterogeneous Panels. Journal of Econometrics 68: 79-113.

23. Pesaran MH, Yongcheol S, Ron PS (1999) Pooled Mean Group Estimation of Dynamic Heterogeneous Panels. Journal of the American Statistical Association 94: 621-34. 
Citation: Abdelbagi E, Azali M, Azman H, Md Nor N (2016) What Factors Determines the FDI Net Flows in Africa? GMM and PMG Techniques. J Glob Econ 4: 170. doi:10.4172/2375-4389.1000170

Page 8 of 8

24. Im KS, Hashem MP, Yongcheol S (2003) Testing for Unit Roots in Heterogeneous Panels. Journal of Econometrics 115: 53-74.

25. Levin A, Chien-fu L, Chia-shang JC (2002) Unit Root Tests in Panel Data: Asymptotic and ÿnite-Sample Properties. Journal of Econometrics 108: 1-24.

26. Irz X, Jyrki N, Xing L (2013) Determinants of Food Price Inflation in Finland-The Role of Energy. Energy Policy 63: 656-63.

27. Pedroni $P$ (2004) Panel Cointegration: Asymptotic and Finite Sample Properties of Pooled Time Series Tests with an Application to the ppp Hypothesis. Econometric Theory 20: 597-625.
28. Chowdhury A, George M (2005) FDI and Growth: A Causal Relationship. WIDER.

29. Kolstad I, Arne W (2012) What Determines Chinese Outward FDI?" Journal of World Business 47: 26-34

30. Tyson JE (2015) Sub-Saharan Africa International Sovereign Bonds. Shaping policy for development.

31. Addis A (2013) African Union African. Economy Outlook.

32. Baddeley A (2003) Working Memory: Looking Back and Looking Forward Nature Reviews Neuroscience 4: 829-39. 